\title{
molecules
}

ISSN 1420-3049

http://www.mdpi.org

Full Paper

\section{Microwave-Assisted Isolation of Essential oil of Cinnamomum iners Reinw. ex Bl.: Comparison with Conventional Hydrodistillation}

\author{
Weerachai Phutdhawong $^{1, *}$, Rungthip Kawaree ${ }^{1,2}$, Samart Sanjaiya ${ }^{1}$, Waya Sengpracha ${ }^{3}$ and \\ Duang Buddhasukh ${ }^{4}$
}

${ }^{1}$ Department of Chemistry, Faculty of Science, Maejo University, Sansai, Chiang Mai 50290, Thailand

${ }^{2}$ Pharmaceutical Sciences Department, Faculty of Pharmacy, Chiang Mai University, Chiang Mai 50202, Thailand

${ }^{3}$ Department of Chemistry, Faculty of Science, Silpakorn University, Nakhonpathom 73000, Thailand

${ }^{4}$ Department of Chemistry, Faculty of Science, Chiang Mai University, Chiang Mai 50202, Thailand

* Author to whom correspondence should be addressed; E-mail: weerachai@mju.ac.th or phutdhawong@gmail.com; Tel: +6653873651, Fax:+6653869410

Received: 22 February 2007; in revised form: 27 April 2007 / Accepted: 27 April 2007 / Published: 30 April 2007

\begin{abstract}
Microwave-assisted hydrodistillation was used to isolate an essential oil from the leaves of Cinnamomum iners Reinw. ex Bl., and the results compared with those obtained by conventional hydrodistillation. The composition of the oil from both methods was found to be similar, and (-)-linalool was found as the main component (30-50\%). The antioxidant activity of the essential oil obtained by both methods was evaluated using DPPH, ABTS, FRAP and lipid peroxidation methods, all of which indicated the same but insignificant activity.
\end{abstract}

Keywords: Microwave, (-)-Linalool, Essential oil, Cinnamomum iners 


\section{Introduction}

Microwave heating has an incontestable place in analytical and organic laboratory practices as a very effective and non-polluting method of activation. There are numerous examples of applications of this technology in sample digestion, organic synthesis, analytical chemistry and the food industry [18]. Microwave energy, with a frequency of $2.45 \mathrm{GHz}$, is well known to have a significant effect on the rates of a variety of processes. The number of reported applications, especially in the food industry, is increasing rapidly [4-6, 8]. The main reason for this increased interest lies in the much shorter operation times achievable. Microwave-assisted extraction of natural compounds is also an alternative to conventional techniques. Essential oils are among the products which have been extracted efficiently from a variety of matrices by this method, and many microwave-assisted essential oil extractions from several plants and subsequent product analyses have been reported [9-15]. However, no such report was found for Cinnamomum iners, a plant in the Cinnamomum genus. This is a large genus, belonging to the family Lauraceae, many species of which yield an essential oil upon distillation [16]. The composition of the oil, and its value and uses to which it is put depend very much on the species that is distilled, as well as the part of the plant which is utilized. The Cinnamomum genus comprises several hundred species which occur naturally in Asia. C. iners is one such species widespread throughout Southest Asia. Known as 'Ob Chuei' in Thai, this plant grows mostly in the northern part of Thailand. Its leaves are traditionally used as an analgesic and antipyretic [17].

A number of papers are available reporting both bioassays and component analysis of Cinnamomum in naturally occurring samples. Antifungal properties of essential oils from eleven species of Cinnamomum were reported, viz C. camphora, C. iners, C. microphyllum, C. mollisimum, C. porectum, C. pubescens, C. rhyncophyllum, C. scortechinii, C. sintoc, C. suvabenium and C. zeylanicum [18]. Amylase inhibitor properties were reported for C. cassia Blume, C. zeylanicum Nees, C. obtusifolium Nees, C. sieboldii Meisn, C. burmanni Blume and C. iners Reinw. ex Blume [19]. The chemical components of the leaf, bark and wood oils of seven Malaysian Cinnamomum species were analyzed using GC-MS and selective proton NMR [20]. Our literature search revealed one study of $C$. iners Reinw. oil from India reporting 1,8-cineole as a major component (40\%), but this oil was obtained from stem bark [21]. The objective of the work described in this communication was to investigate the components and antioxidant activity of the essential oil from the leaves of $C$. iners obtained by microwave-assisted hydrodistillation, as compared with the normal hydrodistillation.

\section{Results and Discussion}

The extraction time of $30 \mathrm{~min}$ with microwave-assisted hydrodistillation using $800 \mathrm{~W}$ of microwave power provided the same yield of oil (0.12 \%) as that obtained after a 5-hour normal hydrodistillation. The compositions of the oils from both methods were analyzed using GC/MS. Both oils were rich in linalool (ca. 35-50 \%). Identification of all components was performed by a comparison of their mass spectra with literature data (NIST and WILEY) and by comparison of their retention indices (RI) with those in the literature [22, 23]. The gas chromatograms of the essential oils from both methods are presented in Figures 1 and 2, and Table 1 lists the identified components of the oils. The most prominent components found (conventional/microwaved) were linalool (35.56/50.48 
\%), caryophyllene oxide (6.61/0.86 \%), cadinol (6.65/3.37 \%), $\alpha$-cadinol (5.86/3.44 \%), deltacadinene (4.36/3.54\%), viridiflorol (3.87/3.06\%), unidentified (3.58/2.98\%), and caryophyllene (2.83/1.54 \%). It can be seen that most of these components and a few more were obtained in smaller amounts in the microwaved oil, compared with the conventional oil. Furthermore, a few other minor components present in the normal oil were missing altogether in the microwaved oil. On the other hand, there were some minor constituents which appeared only in the microwaved oil.

A possible reason for these minor differences may be the different heat sources used in the two methods. It is known that a microwaved solution is sometimes superheated, with the temperature of the solution being as much as 20 degress higher than normal. This occurs also when tap water is used instead of distilled water [24], as was the case in this present work. Thus, those oil components that are less heat stable, e.g. caryophyllene oxide, might have undergone some decomposition to other compounds not present in the conventional oil.

Figure 1. Gas chromatogram of the hydrodistillate essential oil of $C$. iners leaves. See Experimental for GC conditions and Table 1 for peak identification.

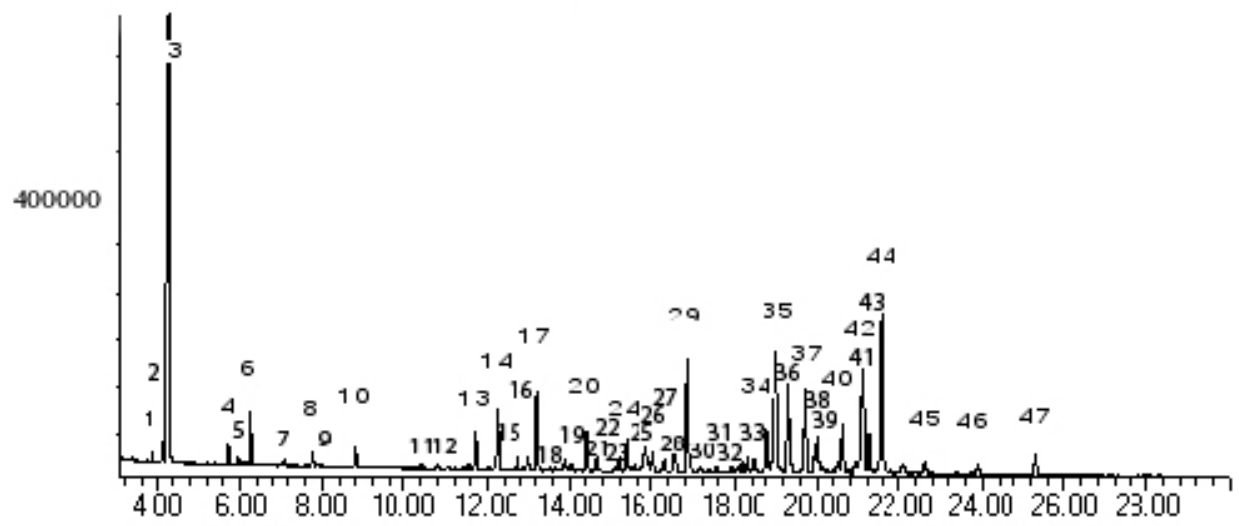

Figure 2. Gas chromatogram of the microwave-assisted hydrodistillate essential oil of $C$. iners leaves. See Experimental for GC conditions and Table 1 for peak identification.

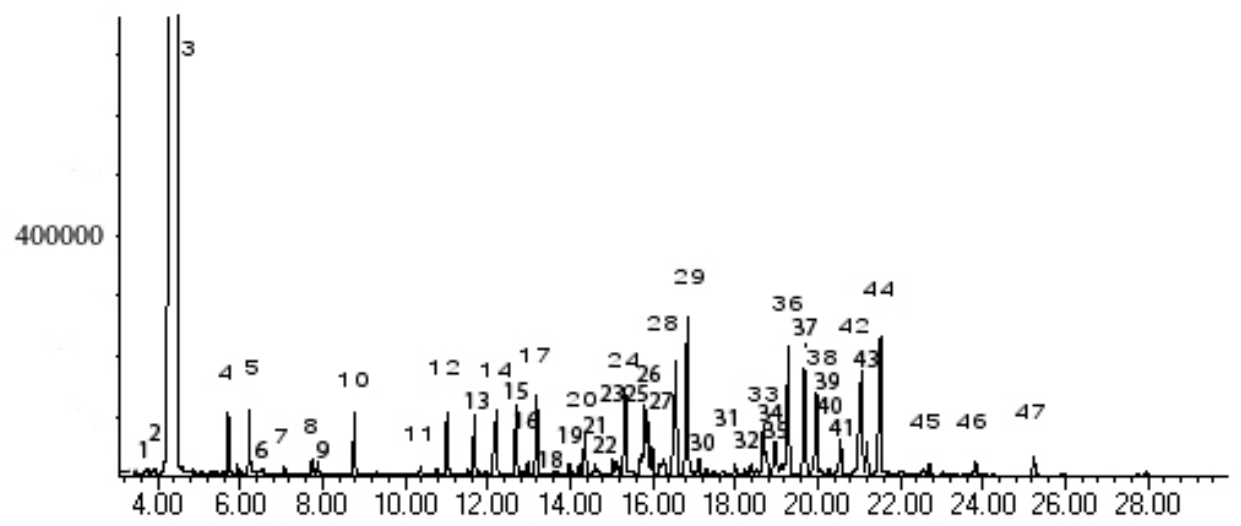


Table 1. Volatile components in leaves of $C$. iners

\begin{tabular}{|c|c|c|c|c|}
\hline \multirow{2}{*}{$\begin{array}{l}\text { Peak } \\
\text { No. }\end{array}$} & \multirow{2}{*}{$\begin{array}{c}\text { Kovát } \\
\text { Retention Index }\end{array}$} & \multirow[b]{2}{*}{ Compounds } & \multicolumn{2}{|c|}{$\%$ Area } \\
\hline & & & Hydrodistillation & $\begin{array}{c}\text { Microwave- } \\
\text { assisted }\end{array}$ \\
\hline 1 & - & cis-linalool oxide & 0.22 & - \\
\hline 2 & - & trans-linaool oxide & 0.53 & - \\
\hline 3 & 1103 & linalool & 36.90 & 55.27 \\
\hline 4 & 1176 & borneol L & 0.52 & 1.02 \\
\hline 5 & 1186 & terpinen-4-ol & 0.19 & 0.14 \\
\hline 6 & 1198 & alpha-terpineol & 1.50 & 0.91 \\
\hline 7 & 1232 & 2,6-octadien-1-ol & - & 0.12 \\
\hline 8 & 1258 & geraniol & 0.37 & 0.25 \\
\hline 9 & 1261 & propanoic acid & - & 0.17 \\
\hline 10 & 1291 & (-)-bornyl acetate & 0.60 & 1.08 \\
\hline 11 & 1343 & cyclohexene & - & 0.17 \\
\hline 12 & 1362 & 3-allyl-6-methoxyphenol & - & 1.29 \\
\hline 13 & 1382 & alpha-copaene & 1.32 & 1.19 \\
\hline 14 & 1396 & beta-elemene & 2.32 & 1.82 \\
\hline 15 & 1410 & dodecanal & 0.82 & 1.51 \\
\hline 16 & 1420 & cis-alpha-bergamotene & 0.46 & 0.30 \\
\hline 17 & 1427 & caryophyllene & 2.94 & 1.69 \\
\hline 18 & 1446 & $(+)$-aromadendrene & 0.45 & - \\
\hline 19 & 1448 & 2-propen-1-ol & - & 0.22 \\
\hline 20 & 1460 & alpha-humulene & 1.63 & 0.97 \\
\hline 21 & 1465 & aromadendrene & - & 0.12 \\
\hline 22 & 1466 & alloaromadendrene & 0.52 & - \\
\hline 23 & 1481 & alpha-amorphene & 0.61 & - \\
\hline 24 & 1485 & germacrene-D & 1.38 & 1.87 \\
\hline 25 & 1490 & beta-selinene & 0.34 & - \\
\hline 26 & 1503 & alpha-muurolene & 0.75 & 0.60 \\
\hline 27 & 1511 & beta-bisabolene & 0.58 & 0.53 \\
\hline 28 & 1519 & alpha-cubebene & 1.22 & 3.30 \\
\hline 29 & 1527 & delta-cadinene & 4.53 & 3.88 \\
\hline 30 & 1564 & epiglobulol & 0.38 & - \\
\hline 31 & 1566 & nerolidol & 0.53 & - \\
\hline 32 & 1571 & palustrol & 0.67 & - \\
\hline 33 & 1577 & unidentified & - & 1.26 \\
\hline 34 & 1581 & spathulenol & 2.04 & 0.46 \\
\hline 35 & 1585 & caryophyllene oxide & 6.85 & 0.95 \\
\hline 36 & 1594 & viridiflorol & 4.01 & 3.36 \\
\hline 37 & 1608 & unidentified & 3.63 & 3.26 \\
\hline 38 & 1617 & tetradecanal & 1.38 & 2.09 \\
\hline 39 & 1639 & calarene & 0.43 & - \\
\hline 40 & 1643 & $\begin{array}{c}\text { naphthalene, 1,2,3,4,4a,7- } \\
\text { hexahydro }\end{array}$ & 2.18 & 0.93 \\
\hline 41 & 1656 & isospathulenol & 0.50 & - \\
\hline 42 & 1662 & alpha-cadinol & 6.10 & 3.78 \\
\hline
\end{tabular}


Table 1. Cont.

\begin{tabular}{|l|l|l|l|l|}
\hline 43 & 1667 & alpha-copaene & 1.71 & 0.72 \\
44 & 1679 & cadinol & 7.03 & 3.70 \\
45 & 1712 & alpha-longipinene & 0.58 & 0.19 \\
46 & 1742 & unidentified & 0.48 & 0.38 \\
47 & 1774 & benzyl benzoate & 0.80 & 0.51 \\
\hline
\end{tabular}

The identification of the major component, linalool, was also performed by separating the pure linalool from the crude oil by PLC. The optical rotation of the isolated linalool was measured, whereby the levorotatory (-) form of linalool was identified, $[\alpha]_{\mathrm{D}}{ }^{24.5}=-22.2$ (4.5, ethanol). Confirmation was obtained from spectroscopic data. The ${ }^{1} \mathrm{H}$-NMR spectrum indicated the presence of three $\mathrm{CH}_{3}$ singlets at $\delta 1.20,1.53$ and 1.61, which was confirmed by DEPT technique, whereby three $\mathrm{CH}_{3}$, three $\mathrm{CH}_{2}$ and two $\mathrm{CH}$ were identified. The protons located on adjacent carbons were assigned by performing a standard COSY experiment. The ${ }^{1} \mathrm{H}$-NMR spectrum was also identical to that given in the literature [25]. The ${ }^{13} \mathrm{C}-\mathrm{NMR}$ spectrum showed 10 signals, of which two at $\delta 73.57$ and 131.90 were assigned to the quaternary carbons. The IR spectrum exhibited a strong broad hydroxy group absorption band $\left(3,396 \mathrm{~cm}^{-1}\right)$.

The antioxidant activities of the oils were evaluated using DPPH, ABTS, FRAP, and lipid peroxidation methods and the results are shown in Table 2. It can be seen that both oils had more or less of the same activity. However, it is obvious that these values for the activity all point to the same conclusion that the activity appears insignificant.

Table 2. Antioxidant activity of $C$. iners volatile oil

\begin{tabular}{|c|c|c|c|}
\hline \multicolumn{2}{|c|}{$\begin{array}{l}\text { DPPH method } \\
\mathrm{IC}_{50}(\mu \mathrm{g} / \mathrm{mL})\end{array}$} & \multicolumn{2}{|c|}{$\begin{array}{c}\text { ABTS method } \\
\text { TEAC (mM/mg) }\end{array}$} \\
\hline Hydrodistillation & $\begin{array}{c}\text { Microwave- } \\
\text { assisted }\end{array}$ & Hydrodistillation & $\begin{array}{c}\text { Microwave- } \\
\text { assisted }\end{array}$ \\
\hline 218.88 & 216.66 & 0.176 & 0.175 \\
\hline \multicolumn{2}{|c|}{$\begin{array}{l}\text { FRAP method } \\
\text { EC1 }(\mu \mathrm{M})\end{array}$} & \multicolumn{2}{|c|}{$\begin{array}{l}\text { Lipid peroxidation method } \\
\text { AA (\%) }\end{array}$} \\
\hline Hydrodistillation & $\begin{array}{c}\text { Microwave- } \\
\text { assisted }\end{array}$ & Hydrodistillation & $\begin{array}{c}\text { Microwave- } \\
\text { assisted }\end{array}$ \\
\hline 387.77 & 387.41 & 13.22 & 13.28 \\
\hline
\end{tabular}

\section{Conclusions}

The use of microwave-assisted hydrodistillation to isolate an essential oil from the leaves of Cinnamomum iners Reinw. ex Bl. provided another example of the advantages of utilizing microwave irradiation as a heat source in isolating essential oils, viz. the much shorter time used in the isolation process to give the same yield of oil. In the case of the essential oil from the leaves of $C$. iners, it was found to be a linalool-rich oil, containing $30-50 \%$ linalool. However, the use of the microwave as heat source for distillation might be the cause for a slight difference of the composition of the oil from that 
of the conventionally obtained oil. The anti-oxidant activity of the oil from both methods was found to be the same but insignificant.

\section{Experimental Section}

\section{Materials}

Fresh leaves of $C$. iners were collected in Nonghan district, Sansai, Chiang Mai, Thailand on 19 December 2003. The plant material was identified by J. Maxwell from the Department of Biology at Chiang Mai University. Voucher specimen was deposited at the Department of Biology Herbarium, Chiang Mai University with Accession No. 22738.

\section{Isolation and Analysis of the Essential Oil}

Fresh leaves (700 g) were homogenized and hydrodistilled for $5 \mathrm{~h}$ using a Clevenger-type apparatus to yield about $0.12 \%$ of yellowish-colored oil with a strong odor. Fresh leaves (200 g) were also homogenized and hydrodistilled at $800 \mathrm{~W}$ for $30 \mathrm{~min}$ using an adapted microwave distillation apparatus which consists of a microwave oven connected to a Clevenger-type apparatus as illustrated in Figure 3, to yield $0.12 \%$ of yellowish-colored oil with a strong odor.

Figure 3. Adapted microwave distillation apparatus

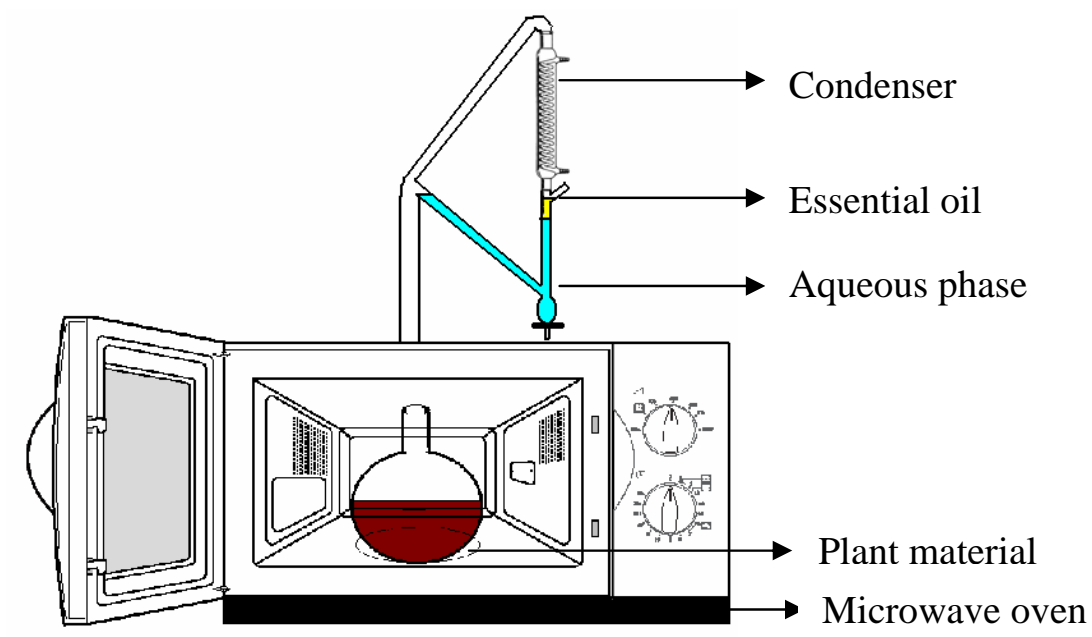

The maximum output power of this adapted microwave apparatus was $1,000 \mathrm{~W}$ with $2,450 \mathrm{MHz}$ of microwave irradiation frequency. The reactor was a $500 \mathrm{~mL}$ short-necked flask. Analytical instruments with the following specifications were used: GC/MS was an Agilent 6890/HP 5975 with a 25m x 0.25 $\mathrm{mm}$ capillary column, (HP-5MS/CB5, film thickness $0.25 \mathrm{~mm}$ ); temperature program: $3 \mathrm{~min}$ isothermal at $100{ }^{\circ} \mathrm{C}$ (no peaks before $100{ }^{\circ} \mathrm{C}$ after first injection), then at $4{ }^{\circ} \mathrm{C} / \mathrm{min}$ to $280{ }^{\circ} \mathrm{C}(5 \mathrm{~min}$ isothermal); carrier gas He. The ionization voltage was $70 \mathrm{eV}$. Programmed-temperature Kováts retention indices (RI) were obtained by GC/MS analysis of an aliquot of the essential oil spiked with an $n$-alkane mixture containing each homologue from $n$-C8 to $n$-C30. IR spectra were run on a PerkinElmer FTIR spectrometer. ${ }^{1} \mathrm{H}-\mathrm{NMR},{ }^{1} \mathrm{H}$-COSY, ${ }^{13} \mathrm{C}-\mathrm{NMR}$ and DEPT were recorded on a Varian 300 
spectrometer, the spectra being measured in $\mathrm{CDCl}_{3}$ at $25{ }^{\circ} \mathrm{C}$ at $300 \mathrm{MHz}\left(100 \mathrm{MHz}\right.$ for $\left.{ }^{13} \mathrm{C}-\mathrm{NMR}\right)$ with TMS as internal reference. Identification of the compounds was based on a comparison of their mass spectra with database (Wiley \& NIST) and spectroscopic data. The optical rotation was measured on a Bellingham + Stanley (Model D) polarimeter. The isolation of linalool from the essential oil was carried out by PLC, with silica gel as adsorbent, and dichloromethane as eluent. The linalool was obtained in 37.5 and $55.7 \%$ yields from the oil obtained from normal and microwave hydrodistillation, respectively. The structural confirmation of the isolated linalool was done spectroscopically by optical rotation, IR, MS and NMR: $[\alpha]_{\mathrm{D}}^{24.5}=-22.2$ (4.5, ethanol); IR (neat) $\mathrm{cm}^{-1}$ : 3369, 2969, 2926, 2854, 1451, 1375, 1113, 995, 920; MS m/z (\% relative intensity): 71 (100), 93 (83), 43 (51), 55 (49), 80 (35), 121 (30); ${ }^{1} \mathrm{H}-\mathrm{NMR}: 1.20$ (3H, s, $\left.\mathrm{CH}_{3}\right), 1.4-1.5$ (2H, m, $\left.\mathrm{CH}_{2}\right), 1.53\left(3 \mathrm{H}, \mathrm{s}, \mathrm{CH}_{3}\right), 1.61$ (3H, s, $\left.\mathrm{CH}_{3}\right), 1.95$ $\left(2 \mathrm{H}, \mathrm{q}, \mathrm{CH}_{2}, J=0.02 \mathrm{~Hz}\right), 2.08(1 \mathrm{H}$, broad s, OH), $4.97(1 \mathrm{H}, \mathrm{d}, \mathrm{CH}, J=0.032 \mathrm{~Hz}), 5.04(1 \mathrm{H}, \mathrm{t}, \mathrm{CH}, J$ $=0.02 \mathrm{~Hz}), 5.13(1 \mathrm{H}, \mathrm{d}, \mathrm{CH}, J=0.054 \mathrm{~Hz}), 5.84(1 \mathrm{H}, \mathrm{dd}, \mathrm{CH}, J=0.035,0.016 \mathrm{~Hz}) ;{ }^{13} \mathrm{C}-\mathrm{NMR}: 17.82$ $\left(\mathrm{CH}_{3}\right)$, $22.97\left(\mathrm{CH}_{2}\right), 25.84\left(\mathrm{CH}_{3}\right), 27.89\left(\mathrm{CH}_{3}\right), 42.28\left(\mathrm{CH}_{2}\right), 73.57(\mathrm{C}), 111.83\left(\mathrm{CH}_{2}\right), 124.58(\mathrm{CH})$, $131.90(\mathrm{C}), 145.24(\mathrm{CH})$.

Antioxidant activity: DPPH method [26]

The hydrodistillate was dissolved in methanol to give a solution of $100 \mathrm{ppm}$ concentration. This sample was further diluted to obtain seven different concentrations (two-fold dilutions). Each concentration was tested in triplicate. A portion of sample solution $(1 \mathrm{~mL})$ was mixed with an equal volume of $0.2 \mathrm{mM}$ DPPH (1,1-diphenyl-2-picrylhydrazyl) in absolute methanol and allowed to stand at room temperature for $30 \mathrm{~min}$. The absorbance (A) was then measured at $514.5 \mathrm{~nm}$ (Hitachi U-2001 UV-spectrophotometer). Vitamin E was tested in the same system as a positive control. The results were expressed as percentage inhibition. The percent inhibition was calculated from the equation: \% inhibition $=\left[\left(\mathrm{A}_{\text {control }}-\mathrm{A}_{\text {sample }}\right) / \mathrm{A}_{\text {control }}\right] \times 100 . \mathrm{IC}_{50}$ value (inhibition concentration of sample required to scavenge DPPH radical by $50 \%$ ) was obtained by linear regression analysis of the dose-response curve plot (\% inhibition versus concentration).

\section{ABTS Method [27]}

The antioxidant activity of the essential oils was measured by the ABTS (2,2'-azino-bis(3ethylbenzthiazoline-6-sulfonic acid) radical cation $\left(\mathrm{ABTS}^{+}\right)$decolourisation assay involving preformed ABTS radical cation (ref). ABTS was dissolved in water to a $7 \mathrm{mM}$ concentration. ABTS radical cation was produced by reacting ABTS stock solution with $2.45 \mathrm{mM}$ potassium persulfate in water and allowing the mixture to stand in the dark at low temperature for 16-18 h before use. The solution was diluted in ethanol $(1: 20 \mathrm{v} / \mathrm{v})$ to give an absorbance at $750 \mathrm{~nm}$ of $0.800 \pm 0.200$. The stock solutions of volatile oil and BHT $(1 \mathrm{mg} / \mathrm{ml})$ were prepared in ethanol.

\section{Ferric Reducing Antioxidant Power (FRAP) [28]}

The FRAP assay was carried out by the method of Benzie and Strain [26] with some modifications. FRAP reagent containing $10 \mathrm{mmol} / \mathrm{L} \mathrm{TPTZ}$ in $40 \mathrm{mmol} / \mathrm{L} \mathrm{HCl}(5 \mathrm{~mL})$ plus $20 \mathrm{mmol} / \mathrm{L} \mathrm{FeCl}_{3} \cdot 6 \mathrm{H}_{2} \mathrm{O}$ (5 
$\mathrm{mL}$ ) and $0.3 \mathrm{~mol} / \mathrm{L}$ acetate buffer $(50 \mathrm{~mL}, \mathrm{pH} 3.6)$ was used. The FRAP reagent (180 $\mu \mathrm{L})$ was mixed with sample or standard $(20 \mu \mathrm{L})$ and the absorbance at $595 \mathrm{~nm}$ was measured at $15 \mathrm{~min}$, using a microplate reader. Ethanol was used for control. Ethanolic solutions of $\mathrm{FeSO}_{4} \cdot 7 \mathrm{H}_{2} \mathrm{O}$ of known $\mathrm{Fe}(\mathrm{II})$ concentration, ranging from 5-50 $\mu \mathrm{mol} / \mathrm{L}$ (final concentration), was used for the preparation of the calibration curve. The parameter Equivalent Concentration $\left(\mathrm{EC}_{1}\right)$ was defined as the concentration of antioxidant having a ferric-TPTZ reducing ability equivalent to that of $1 \mathrm{mmol} / \mathrm{L} \mathrm{FeSO} \cdot 7 \mathrm{H}_{2} \mathrm{O}$. $\mathrm{EC}_{1}$ was calculated as the concentration of antioxidant giving an increase in the FRAP assay equivalent to the theoretical absorbance value of a $1 \mathrm{mmol} / \mathrm{l}$ concentration of Fe (II) solution, determined using the corresponding regression equation.

\section{Lipid Peroxidation ( $\beta$-Carotene Bleaching Method) [29]}

Lipid Peroxidation assay was modifed by the method of Miller [30]. A solution of $\beta$-carotene was prepared by dissolving $\beta$-carotene ( $2 \mathrm{mg}$ ) in chloroform $(2 \mathrm{~mL})$ and mixing this with linoleic acid (50 $\mathrm{mg})$ and Tween $20(50 \mathrm{mg})$. This solution $(2 \mathrm{~mL})$ was transferred into a $100 \mathrm{~mL}$ round bottom flask. After the chloroform was removed under vacuum, aerated distilled water $(50 \mathrm{~mL})$ was added to the flask with vigorous shaking. The same procedure was repeated without $\beta$-carotene as negative control. Aliquots $(180 \mu \mathrm{L})$ of this emulsion were transferred into different plates containing the essential oil $(20 \mu \mathrm{L})$. As soon as the emulsion was added to each plate, the zero time absorbance was measured at $490 \mathrm{~nm}$, using a microplate reader. The plates were placed at $45^{\circ} \mathrm{C}$ in an incubator and the absorbance was measured after 150 minutes. A blank, devoid of $\beta$-carotene, was prepared for background subtraction. The same procedure was repeated with the volatile oil $(1 \mathrm{mg} / \mathrm{mL})$, as positive control. Antioxidant activity was calculated using the following equation:

$$
\text { Antioxidant activity }=100 \times 1 \text { - } \text { (Absorbance }_{\underline{t} \underline{ }} \text { - Absorbance } \underline{\underline{1150}} \underline{\text { of sample }}
$$

(Absorbance ${ }_{t 0}-$ Absorbance $_{\mathrm{t} 150}$ ) of control

\section{Acknowledgements}

The financial support from Thailand Research Foundation (grant code: RMU5080006) to W. P. is gratefully acknowledged. We would like to thank Mr Suttiruk Plonjarean from the Department of Agronomy, Faculty of Agricultural Production, Maejo University for his help in the collection of plant material.

\section{References and Notes}

1. Phutdhawong, W.; Buddhasukh, D.; Pyne, S.; Rujiwatra, A.; Pakawatchai, C. Microwave-assisted facile synthesis and crystal structure of cis-9,10,11,15-tetrahydro-9,10[3',4']-furanoanthracene12,14-dione. Synth. Comm. 2006, 36, 881-883.

2. Phutdhawong, W.; Buddhasukh, D. Facile microwave-assisted synthesis of 9,10-dihydro-9,10ethanoanthracene-11-carboxylic acid methyl ester. Molecules 2005, 10, 1409-1412.

3. Bougrin, K.; Loupy, A.; Soufiaoui, M. Microwave-assisted solvent-free heterocyclic synthesis. $J$. Photochem. Photobiol. C: Photochem. Rev. 2005, 6, 139-167. 
4. Venkatesh, M. S.; Raghavan, G. S. V. An Overview of Microwave Processing and Dielectric Properties of Agri-food Materials. Biosyst. Eng. 2004, 88, 1-18.

5. Wang, L.; Sun, D.-W. Recent developments in numerical modelling of heating and cooling processes in the food industry-a review. Trends Food Sci. Tech. 2003, 14, 408-423.

6. Li, B.; Sun, D.-W. Novel methods for rapid freezing and thawing of foods - a review. J. Food Eng. 2002, 54, 175-182.

7. Lidstrom, P.; Tierney, J.; Wathey, B.; Westman, J. Microwave assisted organic synthesis-a review. Tetrahedron 2001, 57, 9225-9283.

8. Zhang, M.; Tang, J.; Mujumdar, A. S.; Wang, S. Trends in microwave-related drying of fruits and vegetables. Trends Food Sci. Tech. 2006, 17, 524-534.

9. Lucchesi, M. E.; Smadja, J.; Bradshaw, S.; Louw, W.; Chemat, F. Solvent free microwave extraction of Elletaria cardamomum L.: A multivariate study of a new technique for the extraction of essential oil. J. Food Eng. 2007, 79, 1079-1086.

10. Ferhat, M. A.; Meklati, B. Y.; Smadja, J.; Chemat, F. An improved microwave Clevenger apparatus for distillation of essential oils from orange peel. J. Chromatogr. A 2006, 1112, 121126.

11. Deng, C.; Xu, X.; Yao, N.; Li, N.; Zhang, X. Rapid determination of essential oil compounds in Artemisia Selengensis Turcz by gas chromatography-mass spectrometry with microwave distillation and simultaneous solid-phase microextraction. Anal. Chim. Acta 2006, 556, 289-294.

12. Wang, Z.; Ding, L.; Li, T.; Zhou, X.; Wang, L.; Zhang, H.; Liu, L.; Li, Y.; Liu, Z.; Wang, H.; Zeng, H.; He H. Improved solvent-free microwave extraction of essential oil from dried Cuminum cyminum L. and Zanthoxylum bungeanum Maxim. J. Chromatogr. A 2006, 1102, 11-17.

13. Chemat, F.; Lucchesi, M. E.; Smadja, J.; Favretto, L.; Colnaghi, G.; Visinoni, F. Microwave accelerated steam distillation of essential oil from lavender: A rapid, clean and environmentally friendly approach. Anal. Chim. Acta 2006, 555, 157-160.

14. Tigrine-Kordjani, N.; Meklati, B. Y.; Chemat, F. Microwave 'dry' distillation as a useful tool for extraction of edible essential oils. Int. J. Aromather. 2006, 16, 141-147.

15. Lucchesi, M. E.; Chemat, F.; Smadja, J. Solvent-free microwave extraction of essential oil from aromatic herbs: comparison with conventional hydro-distillation. J. Chromatogr A 2004, 1043, 323-327.

16. Wannissorn, B.; Jarikasem, S.; Siriwangchai, T.; Thubthimthed, S. Antibacterial properties of essential oils from Thai medicinal plants. Fitoterapia 2005, 76, 233-236.

17. Pormjit, S. Pharmacognosy; R. D. P. Press: BKK, 1989; p 86-87.

18. Mastura, M.; Azah, M. A. N.; Khozirah, S.; Mawardi, R.; Manaf, A. A. Anticandidal and antidermatophytic activity of Cinnamomum species essential oils. Cytobios 1999, 98, 17-23

19. Iida, N.; Ishii, R.; Hakamata, J.; Myamoto, S.; Oozeki, H. Amylase inhibitors for food and pharmaceutical. Jpn. Kokai Tokkyo Koho. Patent No. JP 09040572, 1997

20. Bin Jantan, I.; Goh, S. H. Essential oils of Cinnamomum species from Peninsular Malaysia. $J$. Essent. Oil Res. 1992, 4, 161-171.

21. Baruah, A.; Nath, S. C.; Hazarika, A. K. Stem bark oil of Cinnamomum iners Reinw. Indian Perfumer 2001, 45, 261-263. 
22. Adams, R. P. Identification of Essential Oil Components by GC/MS; Allured Publishing Corporation: Carol Stream, ILL, USA, 1995.

23. Davies, N. W. Gas chromatographic retention indices of monoterpenes and sesquiterpenes on methyl silicon and Carbowax 20M phases. J. Chromatogr. A 1990, 503, 1-24.

24. Pelle, L.; Jason, T.; Bernard, W.; Jacob, W. Microwave Assisted Organic Synthesis-a Review. Tetrahedron, 2001, 57, 9225-9283.

25. Bryliakov, K. P.; Talsi, E. P.; Stas’ko, S. N.; Kholdeeva, O. A.; Popov, S. A.;Tkachev, A. V. Stereoselective oxidation of linalool with tert-butyl hydroperoxide, catalyzed by a vanadium(V) complex with a chiral terpenoid ligand. J. Mol. Catal. A: Chem. 2003, 194, 79-88.

26. Phutdhawong, W.; Donchai, A.; Korth, J.; Pyne, S. G.; Picha, P.; Ngamkham, J.; Buddhasukh, D. The components and anticancer activity of the volatile oil from Streblus asper. Flav. Frag. J. 2004, 19, 445-447

27. Roberta, R.; Nicoletta, P.; Yang, M.; Rice-Evans, C. Antioxidant activity applying an improved ABTS radical catin decolorization assay. Free Rad. Biol. Med. 1999, 26, 1231-1237.

28. Benzie, I. F. F.; Strain, J. J. The Ferric Reducing Ability of Plasma (FRAP) as a Measure of Antioxidant Power: The FRAP Assay. Anal. Biochem. 1996, 239, 70-76.

29. Jiang, P.; Burczynski, F.; Campbell, C.; Pierce, G.; Austria, J. A.; Briggs, C. J. Rutin and flavonoid contents in three buckwheat species Fagopyrum esculentum, F. tataricum, and F. homotropicum and their protective effects against lipid peroxidation. Food Res. Int. 2007, 40, 356-364.

30. Miller, N. J. A simplified method for the evaluation of antioxidants. J. Am. Oil. Chem. Soc. 1971, 48, 91.

Sample Availability: Samples of (-)-linalool are available from authors.

(C) 2007 by MDPI (http://www.mdpi.org). Reproduction is permitted for noncommercial purposes. 